\title{
津波による船舶の漂流とその対策に関する基礎研究
}

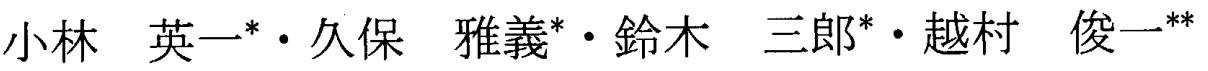

\section{A Basic Study on Evacuation Maneuver from Tsunami Attack}

\author{
Eiichi KOBAYASHI, Masayoshi KUBO, \\ Syunichi KOSHIMURA and Saburo SUZUKI
}

\begin{abstract}
We are concerned about the occurrence of Tokai, Tonankai and Nankai earthquakes in Nankai Trough located at southern Japan sea area. The possibility of the occurrence is estimated as over 50 percent in these 30 years as of January, 2005. The tsunami by the earthquake attacks to the coastal area of Japan and generates not only the raise of sea surface but strong horizontal flow. The ships in the bay are forced to move by the current and such unexpected phenomena may occur as the addition of large force to a pier, uncontrollable lateral motion, collision to breakwater and drifting and grounding. It is very important to grasp the drifting motion of the vessel caused by tsunami current and make action guidelines against the attack for the prevention of sea disaster because such accidents bring serious results especially in the ports where dangerous cargoes are unloaded and loaded. From such viewpoints, basic analyses for ship evacuation maneuver from the tsunami attack were carried out and effectiveness of the action was shown.
\end{abstract}

Keywords : tsunami attack, drifting, grounding, collision, evacuation maneuver キーワード: 操維性、津波、船舶漂流、座礁、港外避難

\section{1.はじめに}

地球の表面を覆っているプレートはその下部に存 在するマグマの対流により海嶺で新しく形成され一 年に数センチ程度動き海溝やトラフといういわば溝 で他のプレートの下に沈み込んでいる。ここでは沈 み込む時の相互力によりしばしば地震が発生する。 四国沖の南海トラフでは、記録に残るものとして 1605 年の慶長地震、1 1707 年の宝栄地震、1 854 年の 安政南海および安政東海地震、1944 年の東南海地震、 1946年の南海地震などいずれもマグニチュード 8 ク
ラスの地震が継続的に発生している。そして 2005 年 1 月 1 日を基準にし今後 30 年以内に南海地震が $50 \%$ 、東南海地震が $60 \%$ と高い確率で発生するとさ れている(1)。この地震の発生に伴い津波が発生する がこれが周辺港湾に来襲すると水位の上昇と水平流 れが同時に起こる。このような場合、港湾内の船舶 は漂流したりバースに接触したり、また水位が下が った場合に底触することも考えられる。いずれの場 合も港湾災害に結びつく可能性があるためこのよう な現象の解析・評価とそれに基づく対策の検討は災

* 正会員 神戸大学海事科学部 （T658-0022 神戸市東灘区深江南町 5·1·1） kobayasi@maritime.kobe-u.ac.jp

** 非会員 東北大学大学院工学研究科附属災害制御研究センター 
害をできるだけ小さくするために重要な課題である。 先の研究(2)において津波の来襲により積極的な操船 を行わないと船体が漂流し底触する可能性を示した が、本研究では操船を行うことにより船体漂流を軽 減できるかどうかについての検討をシミュレーショ ン計算により行い、今後の減災対策絞り込みに資す る基礎的なデータを整備することとした。

\section{2. シミュレーションモデル}

\section{1 津波の計算}

津波は地震により海底地形が変動することにより 生ずる波である。津波挙動は水平方向の流速分布が 水媣方向に一様とした非線形長波理論により、Fig. 1 に示す座標系にて、連続の式と運動量保存の式を用 い次のように表すことができる。

$\frac{\partial \eta}{\partial t}+\frac{\partial M}{\partial x_{0}}+\frac{\partial N}{\partial y_{0}}=0$

$\left.\frac{\partial M}{\partial t}+\frac{\partial}{\partial x_{0}} \frac{M^{2}}{D}+\frac{\partial}{\partial y_{0}} \frac{M N}{D}+g D \frac{\partial \eta}{\partial x_{0}}+\frac{\tau_{x}}{\rho}=0\right\}$

$\frac{\partial N}{\partial t}+\frac{\partial}{\partial x_{0}} \frac{M N}{D}+\frac{\partial}{\partial y_{0}} \frac{N^{2}}{D}+g D \frac{\partial \eta}{\partial y_{0}}+\frac{\tau_{y}}{\rho}=0$

ここで

$\eta \quad$ :静水面からの水位上昇， $t$ :時間

$x_{0}, y_{0}$ :水平座標, $\quad g$ :重力加速度

$\rho \quad$ 海水密度, $\quad D$ : 全水深

$\tau_{x}, \tau_{y}: x_{0}, y_{0}$ 方向の海底摩擦

$M, N: x_{0}, y_{0}$ 方向の流量フラックス

である。本論文ではこれを有限差分法にて解いた ${ }^{(3)}$ 。

\section{2 船体漂流の計算}

湾奥が急激に狭まっていたり、水深が急激に変化 するような地形でなければ、港湾内に津波が来襲す

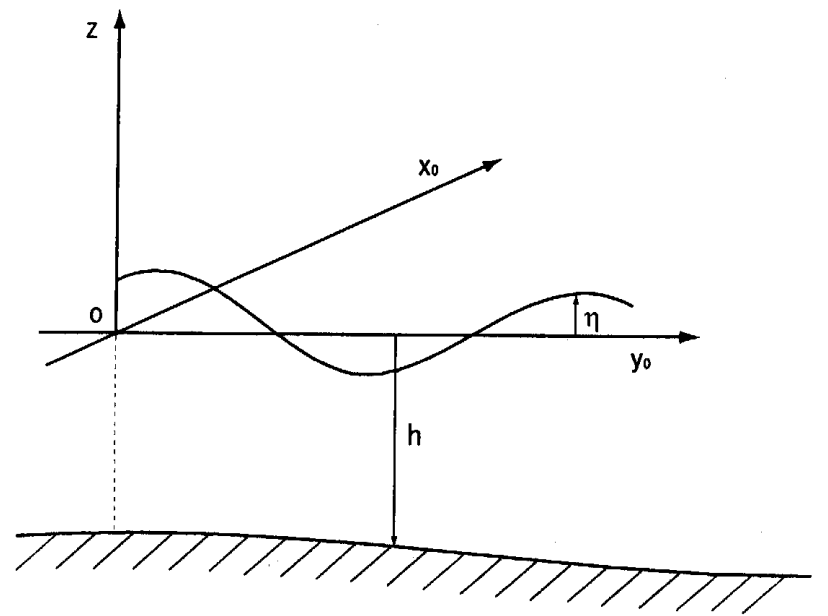

Fig. 1 System of coordinates of tsunami calculation.
ると一般的には水平流れが主体となる。そこで船体 の挙動を表す運動方程式としては、船体と共に移動 しその原点を船体重心とする Fig. 2 に示す座標系を 用いる。船体長手方向に $x$ 軸、それと直交する右手 方向に $y$ 軸、下方に $z$ 軸をとり次のように表した。

$$
\left.\begin{array}{l}
\left(m+m_{x}\right) \dot{u}-\left(m+m_{y}+X_{v r}\right) v r \\
-\left(u_{c 0} \sin \psi-v_{c 0} \cos \psi\right)\left(m_{y}-m_{x}+X_{v r}\right)=X_{H} \\
\left(m+m_{y}\right) \dot{v}+\left(m+m_{x}\right) u r \\
-\left(v_{c 0} \cos \psi+v_{c 0} \sin \psi\right)\left(-m_{y}+m_{x}\right) r=Y_{H} \\
\left(I_{z z}+J_{z z}\right) \dot{r}=N_{H}
\end{array}\right\}
$$

ただし

$$
\begin{aligned}
& m \text { : 船の質量 } \\
& m_{x}, m_{y} \text { : 船の前後方向及び左右方向の付加質量 } \\
& I_{z z} \quad: z \text { 軸回りの船の慣性モーメント } \\
& J_{z z} \quad: z \text { 軸回りの船の付加慣性モーメント } \\
& u, v \quad: x, y \text { 方向の速度成分 } \\
& u_{c 0}, v_{c 0} \text { : 津波水平流の } x_{0}, y_{0} \text { 方向の速度成分 } \\
& r \quad: z \text { 軸回りの回頭角速度 } \\
& \psi \quad \text { : 回頭角 } \\
& \dot{u}, \dot{v}, \dot{r}: u, v, r \text { の時間微分 } \\
& X_{H}, Y_{H}, N_{H} \text { : 船体に作用寸る前後力、左右力及び } \\
& z \text { 軸まわりモーメント }
\end{aligned}
$$

また $X_{H} 、 Y_{H} 、 N_{H}$ については津波により船体に流れ 込む流れが船体近傍では一定方向からの流れで、次 に示すいわゆる潮流抵抗で表現できるとした。また 港湾内では、船底と海底の距離が喫水に比べて小さ くなることがあるため $Y_{H} 、 N_{H}$ については浅水影響 も考慮した。

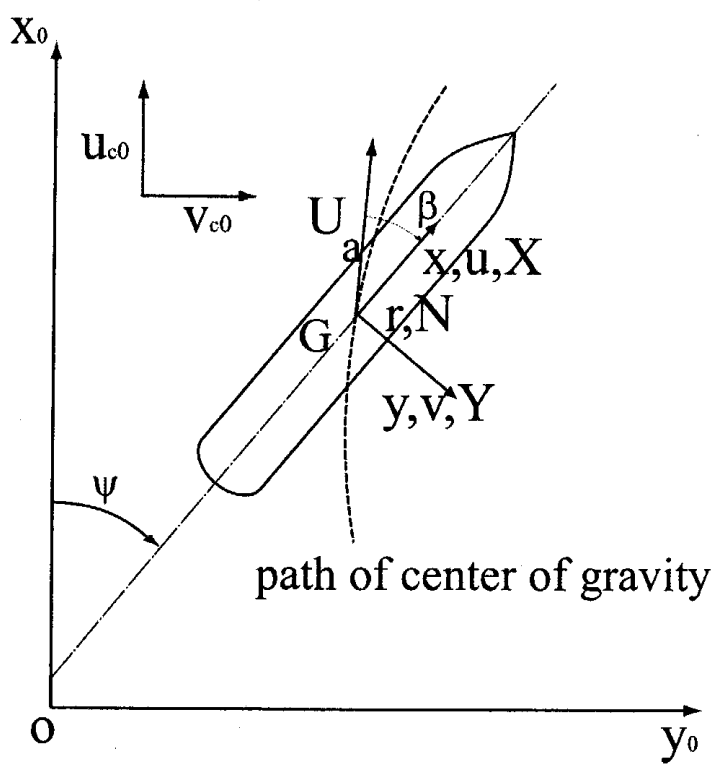

Fig. 2 Coordinate system of ship maneuvering simulation. 


$$
\left.\begin{array}{l}
X_{H}=\frac{\rho}{2} L d U_{c}^{2} C_{D X}\left(\theta_{c}\right) \\
Y_{H}=\frac{\rho}{2} L d U_{c}^{2} C_{D Y}\left(\theta_{c}, H / d\right) \\
N_{H}=\frac{\rho}{2} L^{2} d U_{c}^{2} C_{D N}\left(\theta_{c}, H / d\right)+N_{r}(r, H / d)
\end{array}\right\}
$$

ただし

$$
\begin{array}{ll}
L, d, H & : \text { 船の長さ, 喫水, 水深 } \\
U_{C}, \theta_{C} & : \text { 相対流速及び相対流向 } \\
\rho & : \text { 海水密度 }
\end{array}
$$

$C_{D X}, C_{D Y}, C_{D N}$ :前後方向, 左右方向の潮流抵抗係 数及び潮流モーメント倸数

$N_{r} \quad$ ：回頭運動に伴うモーメント

そして (3)式で示す”流れ”の方向と大きさすなわ ち $U_{C}, \theta_{C}$ が時間と共に変化するとして逐次 (2) 式の 微分方程式を解き時刻歴計算を行うこととした ${ }^{(2)}$ 。

\section{3. 計算条件}

ここで想定する津波の発生モデルは、中央防災会 議想定の東南海・南海連動型地震を採用した。また 対象水域は先の研究(2) と同じ三重県尾鷲湾とした。 計算対象の船舶はこの尾熟湾内の東邦バースに接岸 する一般的な大きさの Table 1 に要目を示すタンカ 一とし、計算の初期位置は Fig. 3 に示寸ようにバー ス付近の 2 つの状態とした。Case A はこのバースか ら離れ船首を北に向けた場合、Case B は着栈の直前 にタンカーがバースに平行状態にある状態とした。 なお載荷状態は操船が比較的難しいこと、喫水が大 きい方が座礁しやすいことなどの面から、万一災害 が起こった場合の影響が大きいと考えられる満載状 態とした。

(3)式右辺の潮流抵抗係数としては類似船型の実 験值 ${ }^{(4)}$ などを参考に Fig. 4 に示す特性とした。

Table 1 Principal dimensions of the VLCC

\begin{tabular}{|l|l|}
\hline 船長 & $265 \mathrm{~m}$ \\
\hline 幅 & $44.2 \mathrm{~m}$ \\
\hline 喫水 & 15.1 \\
\hline 排水量 & $143,000 \mathrm{t}$ \\
\hline
\end{tabular}

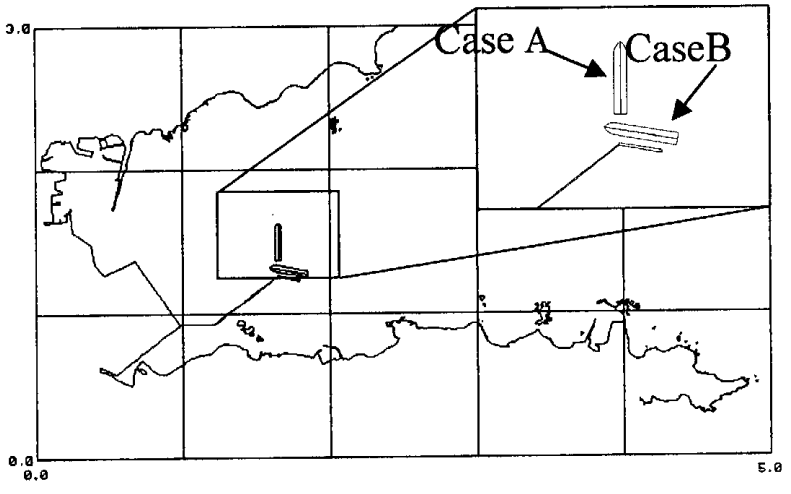

Fig. 3 Initial ship position for evacuation maneuver simulation against the tsunami attack in Owase Bay.

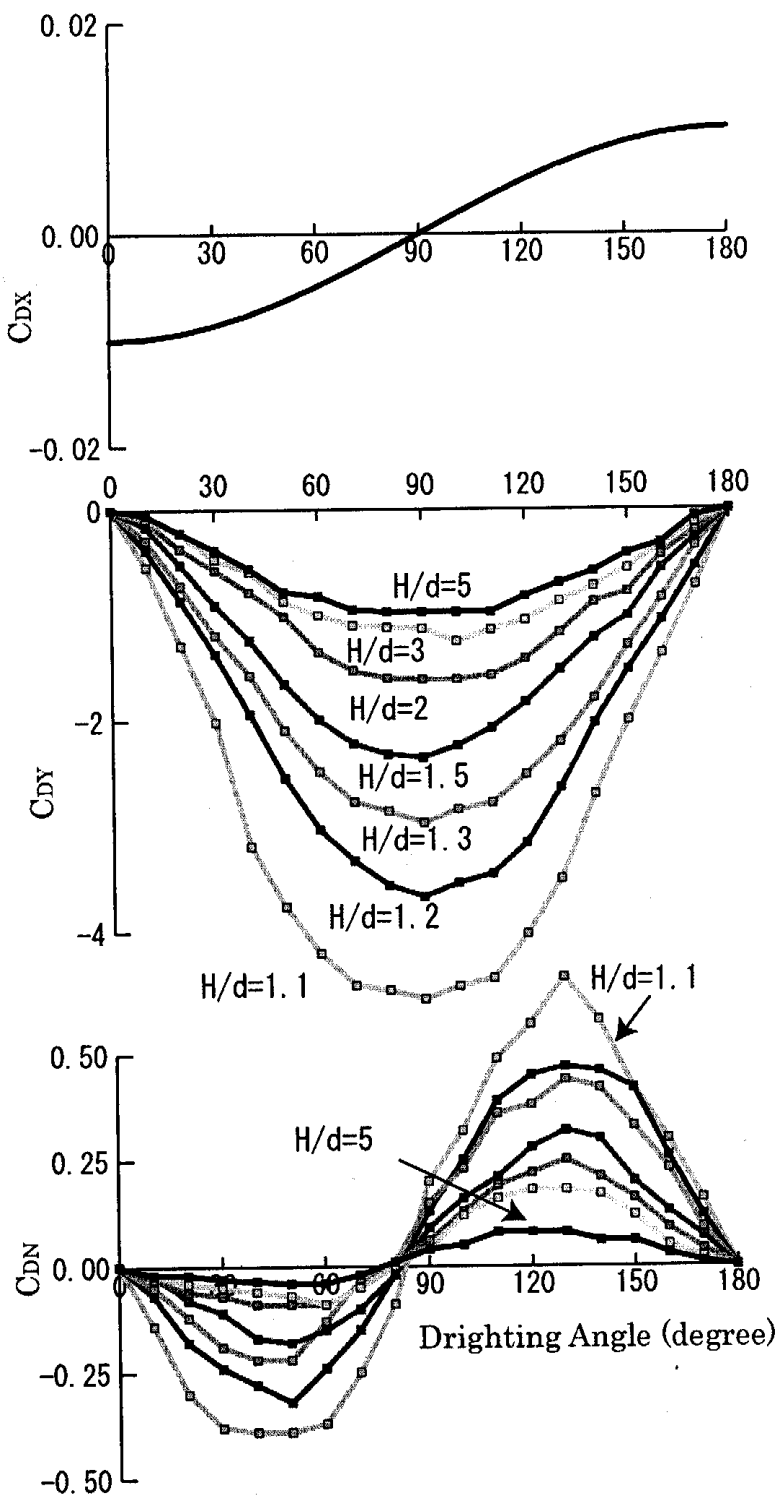

Fig. 4 Current force coefficients 
Fig. 5 はCase A の初期地点における津波による水 位上昇量、東西方向及び南北方向の流速の時刻歴を 示したものである。地震発生後約 20 分程度で最初の 最大水位高的 $4 \mathrm{~m}$ となるが、その時刻までにもすで に水平流は徐々に增大しこの初期最大水面高となる 時刻では南北方向は概ねゼロであるが西向き流速は $1 \mathrm{~m} / \mathrm{sec}$ に達している。すなわちこの位置では東西方 向の流れが卓越していることになる。

Case A の場合は、地震発生後積極的な操船を行わ ないと、緩やかな水平流れにより Fig. 6 に示すよう に津波第一波により西方に流され次に港外方向に引 き戻され次にまた湾奥に押しやられこれを繰り返し ながら北方に移動しやがて浅瀬で底触に至っている。 Case B の場合、Fig. 7 に示すように船舶が流され やがてバースに接触するに至っている。
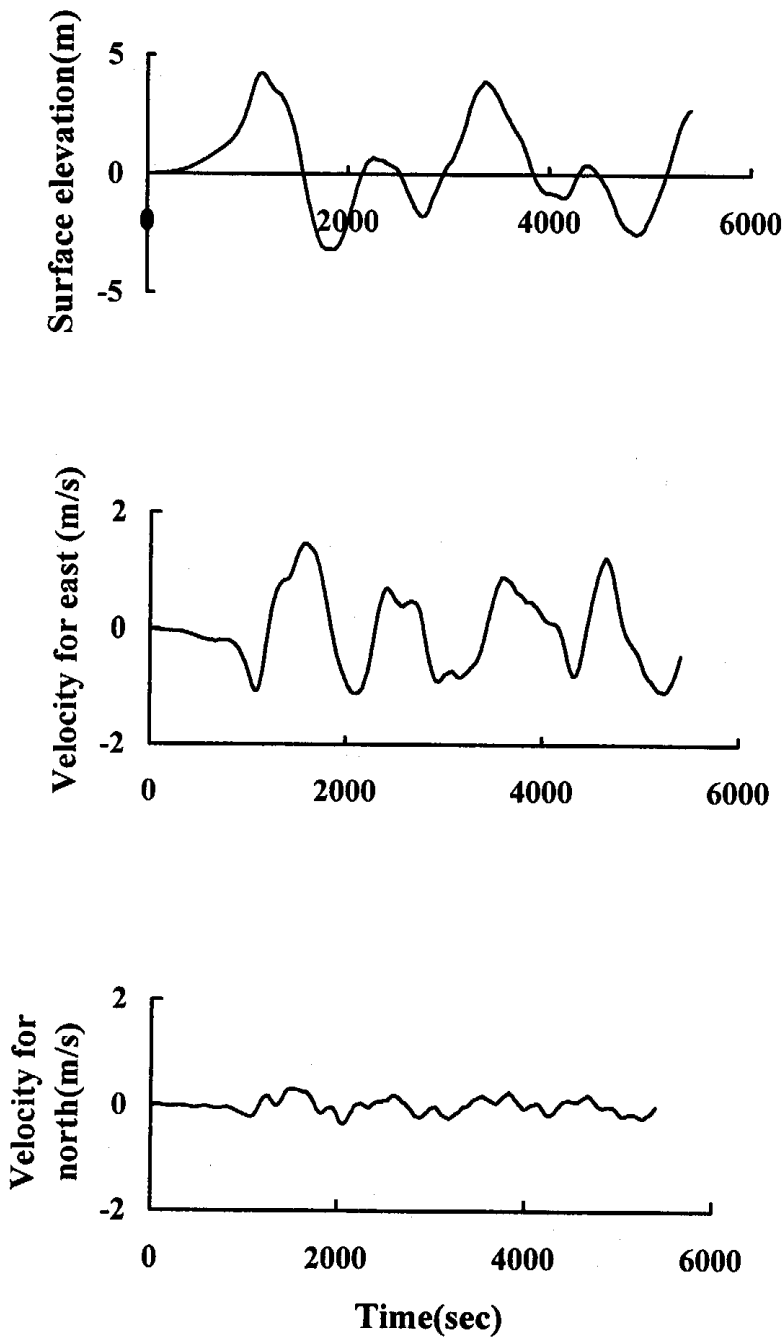

Fig. 5 Time histories of tsunami elevation and velocity components for east and north in Case A.

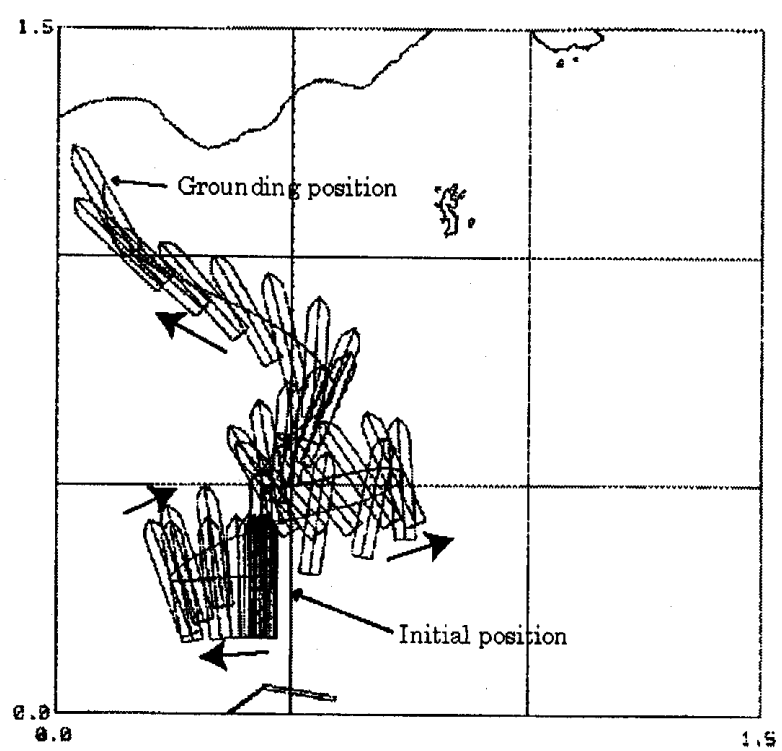

Fig. 6 Ship locus by tsunami attack in Case $A^{(2)}$.

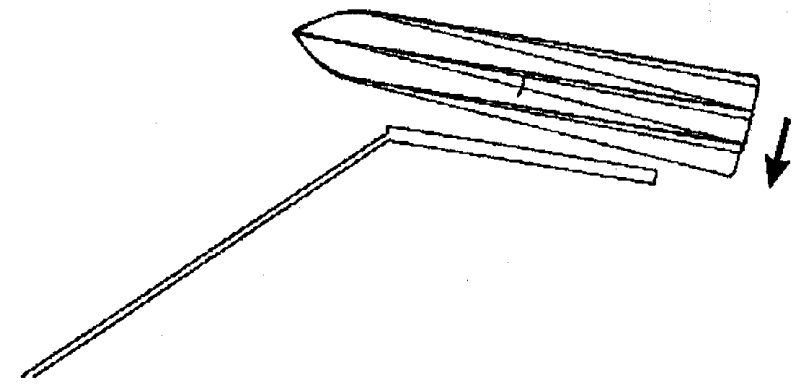

Fig. 7 Ship locus by tsunami attack in Case $\mathrm{B}^{(2)}$.

次に積極的な操船を行うことを考えてみる。Case A の初期位置に船舶がある場合、一般的には主機は 作動できる状態にある。南海トラフ上で地震が発生 したことは、この尾熟湾では直ちに認識できると考 えられるから、早速港外に避難操船を行うと考える。 これをシミュレーション計算で示すため、操舵につ いては次式で示すような自動操船を考㝋た。

$$
\begin{aligned}
& \text { ただし } \\
& \delta: \text { 司令舵角 } \\
& \psi: \text { 方位角 } \\
& \psi^{*}: \text { 目標方位角 } \\
& r: \text { 回頭角速度 } \\
& C_{1}, C_{2}: \text { 比例乗数 }
\end{aligned}
$$$$
\delta=C_{1}\left(\psi-\psi^{*}\right)+C_{2} r
$$

すなわち予め設定した目標方位角 $\psi^{*}$ に対して比 例+微分制御を行う。今回の計算では比例定数 $C_{1}, C_{2}$ 
はそれぞれ試計算などの結果も参考に-10 と-100 と した。また目標方位角 $\psi^{*}$ は、最も一般的と考えられ る航路に適合するよう 80 度とした。また(4)式で示 す指令舵角に対してはその他の外乱に対する余裕を 残すため一般的な最大舵角 35 度とせず上限值を 20 度とした。これに対するシミュレーション結果につ いて、Fig. 8 に舵角、船速、方位角、水位上昇の時 刻歷を示す。また航跡を Fig. 9 に示す。これらから 分かるように、概ね良好に港外一の避難操船が実施 できていることが分かる。

Case B はバース接岸状態で、かつタグが近域に居 ることを想定したシナリオとした。具体的には地震 発生後、10 分間は具体的な操船を行わず、10 分経過 後に、30 トンの曳航力があるタグ二隻を船首尾に配 置し沖合に引き平行離岸作業を開始すると共に、主 機も作動させ、また操舵も行うとした。タグ平行曳 航は地震発生後 10 分後から 5 分間実施するとした。

これに対するシミュレーション結果について、 Fig. 10 にプロペラ回転数、舵角、タグ力、船速、方 位角、水位上昇の時刻歷を示す。また航跡を Fig. 11 に示す。これらから分かるように、方位角にややふ らつきがあるものの、概水良好に港外一の避難操船 が実施できていることが分かる。

\section{4. 考察}

先に述べたように、南海トラフ上で巨大地震が発 生した場合、それによる何らかの衝撃を感ずるであ ろうし、例えそれを見逃したとしても何らかの通信 手段により、操船側には地震発生が殆ど瞬時に伝わ ると考えられる。Case A の場合では、そもそも港外 にむけて進みつつある状態なので、主機作動および 操舵作業は速やかに可能である。今回の計算では、 操舵手による操船を模擬していないが、いわば目標 針路からそれればそれに対して当て舵をとるという 人が行う操船に対応した自動操船に依っている。こ の結果によれば、通常の航路に沿って港外避難操船 を行えば、多少ふらつくものの安全に港外に出るこ とができると考えられる。

Case B の場合はバース位置に船舶があるときに 地震が発生したというシナリオである。この時も先 のケースと同様、地震を体感するのでその発生は認 識できているという想定である。この時係留状況や 諸々の事象確認に時間を要し、実際に船舶を動かす まで 10 分かかったというシナリオにしている。その 後タグによる沖出し、自力操船により、港外避難が 可能との計算結果を得ることができた。
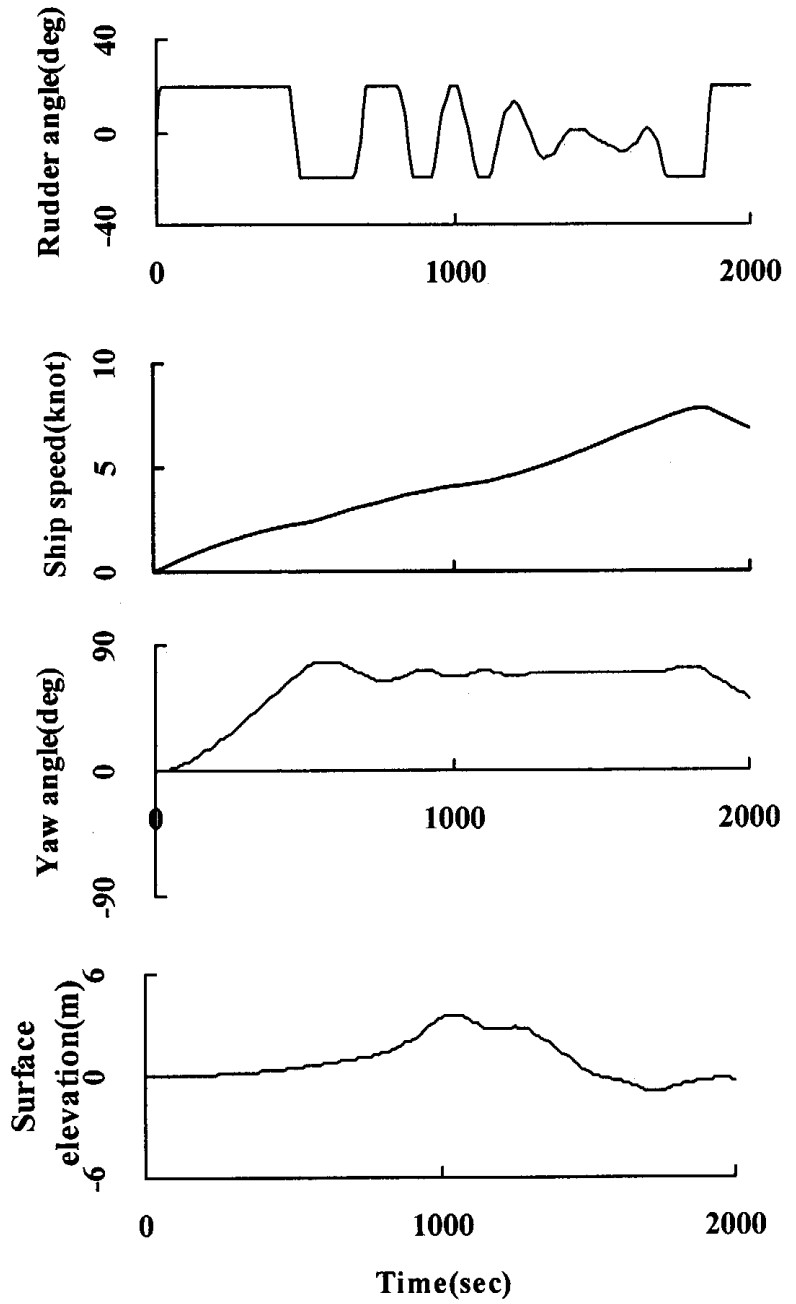

Fig. 8 Time histories of tsunami elevation and velocity components for east and north in Case A.

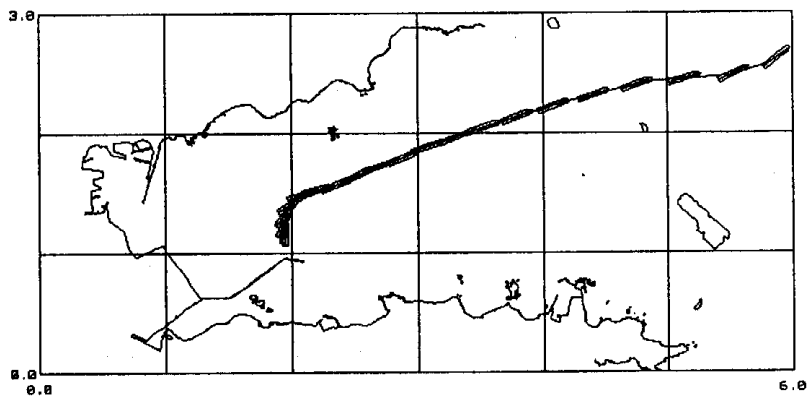

Fig. 9 Ship locus in the evacuation maneuver from tsunami attack in Case A. 

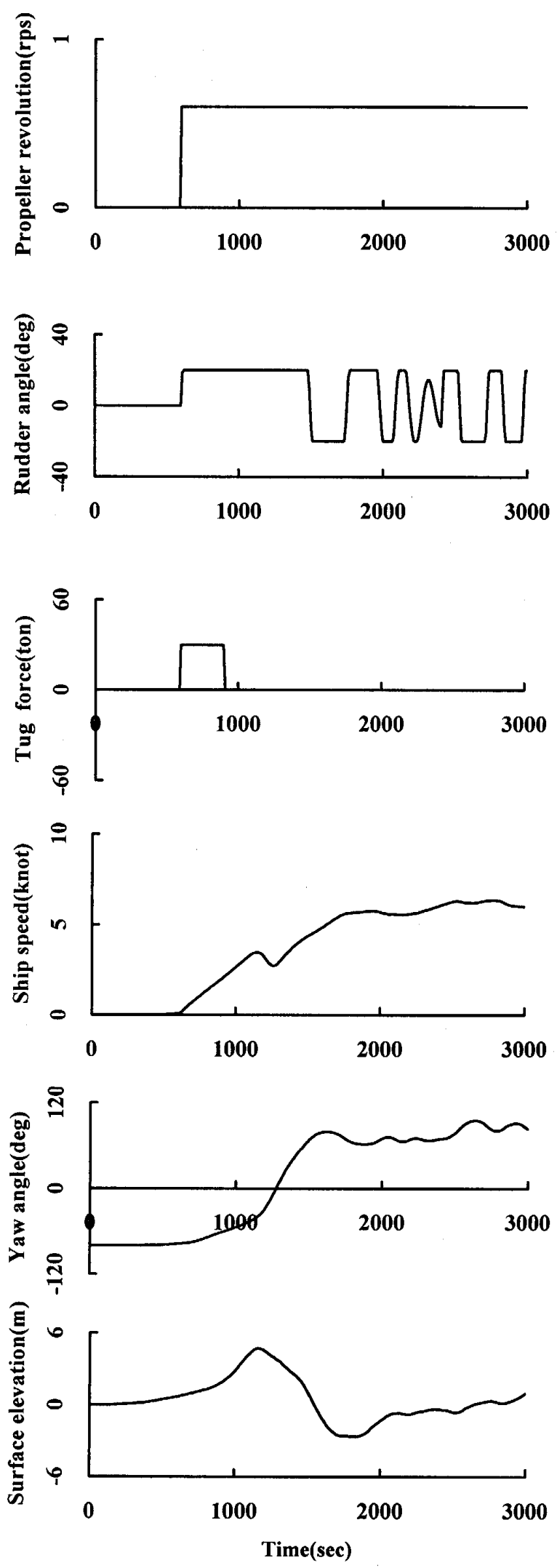

Fig. 10 Time histories of surface elevation, depth in calm and bottom clearance at ship position in Case B.

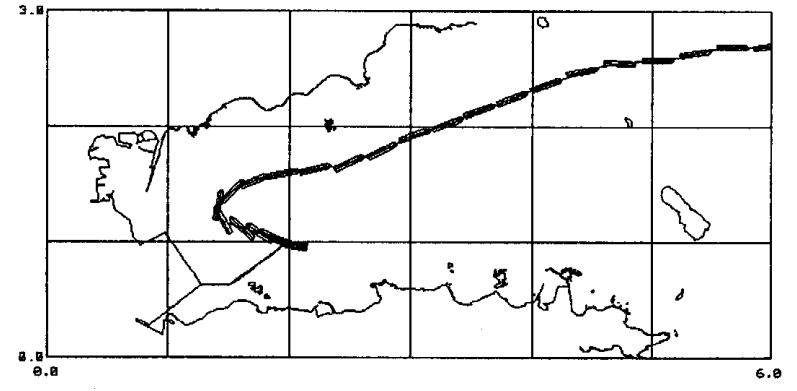

Fig. 11 Ship locus in the evacuation maneuver from tsunami attack in Case B.

この Case B はバース接岸直後と考えれば最も 湾奥にタンカーが入っている時なので、これより手 前、すなわち航路に沿ってタグに伴走あるいは曳航 あるいは押されながら入港中の場合、地震発生後た だちに港外避難操船を行えば安全に避難できること を示唆している。ただ Case B については課題が多 い。今回のケースでは近くにタグがいることにより 地震発生から 10 分後はタグにより曳航するという シナリオだが、そもそもタグ自体が地震発生時にこ のような短時間でこのバース近くまで来られるケー スは少ない。

本論文で取り扱った Case A および Case B は様々 な地震津波被災シナリオのごく限られた一つでしか ない。Case A、Case B の結果からは、尾熟湾の場合、 出入港中の大型タンカーが自力で操船できる状態の 時に地震が発生したならば、概ね安全に港外に避難 できることを示唆するものではある。しかし実際の 揚油中であれば、ごく近くにタグがいる場合でなけ れば港外避難は難しくなることも考えられる。

今後、この地震発生時の対応シナリオについては 操船者 (運航者)、タグ関係者、港湾関係者などの密 接な協議・連携が必要である。またタグ操船者の安 全も考えれば、入港船が自力で避難できる限界をよ り詳細に検討を行うことも対策の一つとして重要で あろう。

また今回はいわゆるオートパイロットを計算ロジ ックに組み込んで計算を行ったが、この推定をより 確実なものとするためには、実時間操船シミュレー タなどを活用し、地震発生、津波来襲についてより 実際に近い状況下で総合的な検証を行う必要がある。

\section{5. 結論}

本研究で尾熟湾を対象として、南海トラフ上で発 生する巨大地震に伴う津波の来襲を受けた場合の船 舶への影響について特に避難操船の見地から検討を 行った。この結果を纏めると次のようになる。 
（1）尾鴇湾では、バース近くで津波来襲を受け た場合、積極的な操船を行わないと船舶が 漂流し、座礁したり、バースに接触したり する。

（2）主機操作や操舵が直ちに実施できる状態の 出入港中であれば、適切な操船を行うこと により安全に港外避難ができる可能性があ る。

（3）今後操船者、タグ関係者、エネルギ一基地 関係者、港湾管理者などが、この避難操船 について、シナリオ策定および対策につい てより密接な協議を進める必要がある。

（4）それぞれのシナリオについての対策検討に 際し、本研究で試みたようなシミュレーシ ヨンを援用することができる。

（5）今後操船シミュレータを活用しより現実的 な環境下で津波来襲時の避難操船について の検証を行う必要がある。

\section{謝辞}

なお本研究は、文部科学省が推進している大都市 大震災軽減化特別プロジェクトの一環として行った もので、関係者の方々のご協力・ご指導に御礼申し 上げます。

\section{参考文献}

（1）地震調查研究推進本部 地震調查委員会 資料 （別表 1）

http://www.jishin.go.jp/main/chousa/05jan_kakurits u/index.htm, 2005.1

（2）小林英一・越村俊一・久保雅義 : 津波による船 舶の漂流に関する基礎研究，関西造船協会論文 集，第 243 号，pp.49-55，2005.3

(3) Imamura, F.: Review of Tsunami Simulation with a Finite Difference Method, Long-Wave Run-up Models, World Scientific, River Edge, NJ, pp.43-87, 1996.

（4）日本海難防止協会編：超大型船操船の手引き， 成山堂書店, pp.39，1976.

\section{質疑応答}

林美鹤（神戸大学）:

今回は地震発生後 10 分後から避難開始する条件 で計算され、避難可能との結果でしたが、逆に何 分位経過すると避難不可能にあるいは何分後まで なら避難可能なのでしょうか。

\section{小林英一：}

御討論ありがとうございます。現在の結果からは 明確には分かりません。今後様々なケースについ ての計算結果から判断する必要があると考えてい ます。

鶴田三郎 (東京海洋大学) :

シミュレーションでは出航（港）可能となったよ うですが、現実の場面においても出航可能と考え てもよろしいでしょうか。

\section{小林英一：}

御討論ありがとうございます。同じような場面で すと出航可能と考えています。ただそれの検証の ためには操船シミュレータを使うなどさらに詳し い検討が必要と考えています。また害際の津波に ついてはこれと同じものが来るわけではありませ ん。タグの援助も必要ですが、関係者が多岐にわ たりますので、様々な場合について対応できるよ う、関係者と協議しながら、本検討で実施した計 算や、さらに大規模な操船シミュレー夕を使った 検討、さらに避難操船マニュアルの整備などが必 要と考えています。 